\title{
Legal and Voluntary Investor Protection and Early IFRS-adoption: A Study of European Companies
}

\author{
Annelies Renders \\ Ann Gaeremynck \\ K.U.Leuven, Department of Applied Economics \\ Naamsestraat 69 \\ 3000 Leuven - Belgium \\ annelies.renders@econ.kuleuven.be
}

\begin{abstract}
Previous studies (Dumontier and Raffournier, 1998, El-Gazzar et al, 1999; Cuijpers and Buijink, 2004) typically explain the early adoption of IFRS by firm-specific benefits. However, the adoption of IFRS also leads to costs for company insiders, namely less managerial discretion and as a consequence smaller private benefits due to increased disclosure requirements and less accounting method choices. This paper argues that the cost of adopting IFRS depends on characteristics of the institutional environment, more specifically the level of investor protection.

Using a sample of European companies, we find that IFRS is more likely adopted in countries with strong laws protecting investors and/or extensive corporate governance recommendations where the loss of private benefits following IFRS-adoption is lower. Furthermore, the results show that corporate governance recommendations are as effective as hard laws in stimulating IFRS-adoption and that their impact increases as laws become weaker. This suggests that by improving corporate governance codes, countries can easily reduce the extraction of private benefits by managers and enhance the quality of the financial information. However, when looking at specific recommendations and laws, we find that shareholder rights with regard to voting rights and the general meeting need to be regulated by law in order to effectively reduce the level of private benefits.
\end{abstract}

Keywords: early adoption of IFRS; private benefits of control; corporate governance; legal investor protection.

We thank the FWO for the financial support (FWO-project G.0244.02). We gratefully acknowledge the comments of the participants of the $26^{\text {th }}$ Annual European Accounting Association Congress in Seville (2003), of the EIASM Workshop on Implementing IFRS in Brussels (2003), and of the International Accounting Section Midyear Conference of the American Accounting Association in San Diego (2004). We also thank the participants of the Finance and Accounting Seminars at the K.U.Leuven and of the KPMG European doctoral colloquium in Mostov, Czech Republic (2004). Finally, we acknowledge the comments of the discussant and participants of the Accounting Research Day in Antwerp (May 2004) and of the participants of the Accounting Seminar in Tilburg (31 March 2005). Special thanks go to M. Willekens, J. Suys, and W. Landsman.

Previous versions of this paper were titled "The influence of corporate governance recommendations and practices on financial statement quality". 


\section{Introduction}

Over the past two decades, growth in international trade and in capital flows has triggered a rising cross-border economic integration. As a consequence, companies and investors are increasingly confronted with unfamiliar and incomparable accounting standards. This has led to the desire to harmonise accounting standards across countries. In Europe, a harmonisation process already started in the seventies and eighties (Council of the EC, 1978 and 1983). Nevertheless, significant differences between local accounting standards remained due to the incorporation of a considerable number of options in the EC Directives ${ }^{1}$.

To put an end to the problem of incomparability and to increase the usefulness of financial information to users in- and outside the EU, the European Commission decided in 2000 that consolidated financial statements of listed companies should be published using IFRS from 2005 onwards (EC, 2000). Yet even before this decision by the EC, a number of countries, such as France, Belgium, Germany and Italy, already allowed listed companies to adopt IFRS instead of the domestic standards ${ }^{2}$. Other countries have permitted IFRS following the decision of the EC. Hence, until 2005, companies in these countries were free to choose their accounting standards: local GAAP or IFRS. As a result, a number of companies from different countries adopted IFRS before it became mandatory in 2005. These companies are called early adopters. An interesting question is then what drives companies to adopt IFRS before it is compulsory and why have other companies postponed the adoption of IFRS until 2005.

Previous studies (Dumontier and Raffournier, 1998; El-Gazzar et al., 1999 and Cuijpers and Buijink, 2004) investigating the early adoption of IFRS, have focused on the benefits for companies. Firms adopting IFRS are typically internationally oriented with multiple stock listings and considerable cross-border activities. In this study, we incorporate explicitly the costs of IFRS-adoption. The widespread view that the adoption of IFRS has many advantages for both investors and companies does not

\footnotetext{
${ }^{1}$ For instance, in the Netherlands companies were until 2001 allowed to deduct goodwill from equity, while in most other EU countries goodwill was amortized. Moreover, in countries where goodwill was amortized, the maximum amortization period ranged from 5 years (in Belgium) over 20 years (in Austria and France) to 40 years (in Germany).

${ }^{2}$ These countries have allowed the use of IFRS since 1998.
} 
correspond with reality in which only $15 \%$ of the EU companies have adopted IFRS in 2002 (PWC, 2002). In this context, previous studies ignore the fact that managerial discretion and opportunism may play an important role in the decision to adopt IFRS early on (Licht, 2003). As the adoption of IFRS by EU companies is typically associated with an increase in disclosure and a decrease in the number of accounting method choices (Ashbaugh, 2001; Leuz and Verrecchia, 2000; Ashbaugh and Pincus, 2001), it leads to a decline in managerial discretion. This results in turn in a loss of private benefits for company insiders as it becomes more difficult under IFRS to divert corporate assets without being uncovered.

Recent empirical work has found that the private benefits of control which insiders are able to extract differ significantly depending upon the level of investor protection provided by countries (Nenova, 2002; Dyck and Zingales, 2004). So the costs of IFRS-adoption may depend on the level of investor protection offered by the country. We distinguish between two types of investor protection: legal investor protection, or the extent of laws protecting shareholders, and voluntary investor protection, measured by the extent of corporate governance recommendations at country level. Although the legal environment is viewed as having the strongest influence on private benefits of control (Dyck and Zingales, 2004; Coffee, 2001), we include corporate governance recommendations for two reasons. Firstly, the recent accounting scandals, such as Enron, Worldcom and Ahold, have led to a renewed attention for corporate governance as a mechanism to protect investors from self-serving managers and this has given rise to the development of many national corporate governance codes. Secondly, in contrast to changing the legal infrastructure of a country, extending the number of corporate governance recommendations is less expensive and timeconsuming. So through corporate governance the level of investor protection can be enhanced rather cheaply.

This study thus contributes to the current state of the literature by investigating IFRSadoption from a cost-side perspective and by linking the costs of IFRS-adoption to characteristics of the institutional environment, more specifically the level of investor protection provided by countries and the extent of corporate governance recommendations. Using a sample of European companies from countries where IFRS is allowed in 2001, we find that both laws protecting investors and corporate 
governance recommendations have a positive influence on the likelihood of adopting IFRS early on. In other words, in countries with strong investor protection, costs of adopting IFRS are lower. The results also show that laws and recommendations are equally effective in stimulating the early adoption of IFRS. Furthermore, corporate governance recommendations and laws seem to serve as substitutes as the impact of corporate governance recommendations on the early application of IFRS is larger in countries with weak laws. Finally, when we look at specific corporate governance recommendations and laws, we find that not all recommendations have an impact on IFRS-adoption. Recommendations with regard to specific shareholder rights, such as the one share/one vote rule, have no impact although the laws prescribing the same rights do.

The remainder of this paper is organized as follows. In section 2, we give an overview of the existing literature and develop the hypotheses. Section 3 specifies the model and defines the explanatory variables. The sample selection and data gathering are discussed in section 4 . Section 5 presents the results and some sensitivity analyses. Finally, the main conclusions are summarized and a number of implications are discussed in section 6 .

\section{Literature review and hypothesis development}

The separation of ownership from control allows managers and controlling shareholders to pursue their own objectives at the expense of minority shareholders. Accounting standards help to alleviate this agency problem as they regulate the information available to outsiders. The more accurate and detailed the accounting information is, the more difficult it is for an insider to expropriate value without incurring legal penalties or reputational costs (Ferrell, 2004). For instance, La Porta et al. (2004) find that an increase in mandatory disclosure requirements is associated with a substantially lower level of private benefits of control. Dyck and Zingales (2004) show that the extent of disclosure negatively influences the level of private benefits insiders can extract. In lax disclosure regimes with a lot of managerial discretion, insiders are thus able to expropriate more.

The adoption of IFRS is assumed to lower the private benefits of control as it leads to an increase in disclosure and a reduction in accounting method choices compared to 
local GAAP (Ashbaugh, 2001; Ashbaugh and Pincus, 2001; Leuz and Verrecchia, 2000). As a consequence, more information about a firm's operations, assets and ownership is available and managers are less able to conceal their expropriation. The adoption of IFRS is thus assumed to lead to a cost for managers as it leads to a loss of private benefits.

The amount of private benefits insiders have to give up following IFRS-adoption will depend on the level of investor protection offered by countries. In countries with extended investor protection, private benefits of control are already curbed independent of the accounting standards used (Coffee, 2001; Leuz et al., 2003). For instance, Nenova (2003) and Dyck and Zingales (2004) find that the value of private benefits is lower in countries with better protection of investor rights. As a result, in countries with strong legal shareholder protection, the cost of adopting IFRS for insiders will be lower as insiders already limit the extraction of private benefits. For instance, Leuz et al. (2003) find that the level of investor protection determines the level of earnings management in a country. On the other hand, in countries with weak laws protecting shareholders, insiders have many private benefits which may be lost by switching to IFRS. We thus argue that IFRS will be less likely adopted by companies in countries with weak legal shareholder protection.

\section{H1: There is a positive association between the extent of laws protecting shareholders and the early adoption of IFRS.}

In this paper we also include a feature of the institutional environment not yet studied, namely the extent of corporate governance recommendations. The recent accounting scandals have given rise to different initiatives to develop national and international corporate governance codes. Many of these corporate governance codes, such as the OECD Principles of Corporate Governance (1999), state that the corporate governance framework should ensure the disclosure of timely and accurate information. Besides, many codes formulate recommendations with regard to the rights of shareholders, such as the right to appoint management. We thus view the extent of corporate governance recommendations as a measure of voluntary investor protection. 
The aim of a corporate governance system is to align managerial and shareholders' interests and in doing so it will minimize the adverse effects of the agency problem. Therefore, extended corporate governance recommendations may incite insiders to reduce their level of expropriation. For instance, the presence of independent directors on the board of directors will enhance the monitoring of managers and will thus reduce their ability to extract private benefits. As managers are already limited in the amount of private benefits they are able to expropriate, the adoption of IFRS is less costly for them. So, similar as with laws, we assume a positive relation between the extent of corporate governance recommendations and the early adoption of IFRS. This brings us to our second hypothesis:

\section{H2: There is a positive association between the extent of corporate governance recommendations and the early adoption of IFRS.}

Furthermore, as corporate governance recommendations are not mandatory and can thus not be enforced by any authoritative body, we believe that their effect on IFRSadoption will be smaller than the effect of laws. So our third hypothesis is formulated as follows:

\section{H3: The impact of corporate governance recommendations on the early adoption of} IFRS is smaller than the impact of laws protecting shareholders.

Finally, we also formulate a hypothesis with respect to the relation between corporate governance recommendations and laws protecting investors. According to Black (2001) alternative sources of protection become more important if legal rules are too weak to provide protection. So, we expect recommendations and laws to serve as substitutes. In countries with weak laws protecting investors, the private benefits for insiders are high. Extensive corporate governance recommendations could in these countries lead to companies being less inclined to extract value, even though laws protecting investors are lacking. In other words, companies in countries with weak legal investor protection will refrain from adopting IFRS, but this effect can be countered by increasing the number of corporate governance recommendations. We thus expect that the impact of corporate governance recommendations will become 
more important as legal investor protection decreases. Our final hypothesis is formulated as follows:

\section{H4: The impact of corporate governance recommendations on the early adoption of} IFRS increases as the extent of laws decreases.

\section{Model specification and variable measurement}

Given the hypotheses developed in the previous section, the early adoption of IFRS is explained by the extent of corporate governance recommendations, the degree of legal investor protection, the interaction between these two variables and some country and company control variables. The model looks as follows:

$$
\begin{aligned}
\text { P }_{\left(\text {IFRS }_{i j}\right)=} & \alpha+\beta_{1}{\text { LAW } 2001_{j}}_{j} \beta_{2} \text { CGI }_{j}+\beta_{3} \text { CGI }_{j} * L_{2 A W} 2001_{j} \\
& +\beta_{4} \text { DIST_IFRS }_{j}+\beta_{5} \text { MARKET_CAP }_{j}+\beta_{6} \text { EM }_{j} \\
& +\beta_{7} \text { SIZE }_{\mathrm{i}}+\beta_{8} \text { AUDITOR }_{\mathrm{i}}+\beta_{9} \text { FINANCIAL_IND }_{\mathrm{i}} \\
& +\beta_{10} \text { LISTINGS }_{\mathrm{i}}+\beta_{11} \text { OWNERSHIP }_{\mathrm{i}}+\beta_{12} \text { CAPITAL_INT }_{\mathrm{i}} \\
& +\varepsilon_{\mathrm{ij}}
\end{aligned}
$$

$$
\begin{array}{ll}
\text { with } & \mathrm{i}=\text { company } \\
& \mathrm{j}=\text { country }
\end{array}
$$

The variable IFRS $_{\mathbf{i j}}$ is an indicator variable, which equals 1 if company $\mathrm{i}$ in country $\mathrm{j}$ applies IFRS in 2001. A corporate governance index $\left(\mathbf{C G} \mathbf{I}_{\mathbf{j}}\right)$ is developed, measuring the extent of corporate governance recommendations of each country in the study. Two sources are used to develop the index: the OECD Principles of Corporate Governance (1999) and the Comparative Study of Corporate Governance Codes published by the European Commission in $2002^{3}$. Forty-three recommendations by the OECD are retained for our index (see Table 1). We complemented these 43 recommendations with 7 recommendations from the EC's Comparative Study (principles 20 to 26 in Table 1). The reason is that the OECD code is rather silent on

\footnotetext{
3 The OECD principles are used as a benchmark to validate the country corporate governance codes because they are widely accepted and referred to. For instance, the World Bank uses these principles as a benchmark to draw up country corporate governance assessments. Also the IMF and the International Corporate Governance Network (ICGN) subscribe to the principles of the OECD.
} 
the different tasks of the board committees (e.g. key functions). However, as for instance the audit committee has an important role in verifying the accuracy of the accounting information, board committee characteristics should be included in the index.

Insert Table 1 about here

These 50 recommendations are then grouped into five categories: general principles, principles concerning the board of directors, the board committees and the shareholders and principles with regard to disclosure (see Table 1). Each category is again divided in a number of subcategories. The general principles comprehend the compliance-mechanism and scope of the corporate governance codes. Principles on the board of directors include its mission, key functions and independence. Principles on the board committees are divided into principles on the recommended committees, their key functions and their independence. Finally, principles concerning shareholders include their protection and the rights of the general meeting and principles on disclosure cover quality, timing and content.

The scoring of the individual principles is straightforward: the principles are either present in a country code (YES, score equals 1 ) or not (NO, score equals 0 ). For some principles, however, such as the independence of the board of directors (principle 15) and of the board committees (principles 27 to 32), the score ranges between 0 and 2. The score in this case equals 2 if a code recommends that the majority of directors or members of the committees should be independent. The score is equal to 1 if independence is only required for a minimum number of directors. If this topic is not covered by the codes or if the number of independent members is not specified, the score is 0 . We then divide the scores on the independence of the board of directors and board committees by 2 , so that the final score on these principles lies between 0 and 1 .

Finally, the scores on the individual principles are summed up to arrive at a score per subcategory. We rescale this score per subcategory to 1 so that each subcategory has 
an equal weighting in the total score of the index ${ }^{4}$. We obtain $\mathbf{C G} \mathbf{I}_{\mathbf{j}}$ by dividing the total score of each country by 13 , i.e. the maximum score obtainable on the index. The expected sign for $\mathbf{C G} \mathbf{I}_{\mathbf{j}}$ in the model is positive: the more detailed and extended the recommendations are the more likely IFRS will be applied as the costs are lower.

We introduce in our model also a measure for the extent of legal shareholder protection in a country $\left(\mathbf{L A W 2 0 0 1} \mathbf{1}_{\mathbf{j}}\right.$ ). We base our measure on a proxy developed by La Porta et al. (1998). This proxy is a combination of 7 shareholder rights, so-called anti-director rights, and is based on the company law and commercial code of countries in 1993. These anti-director rights cover, for instance, ease of participation in corporate voting and legal protection against expropriation by management. We have updated this variable to 2001, which is the sample period studied, using the legal system overview in the EC's Comparative Study of Corporate Governance Codes (2002). Furthermore, we do not only update this variable but also extend it to make it more in line with our corporate governance index. Our law index for 2001 comprehends 27 principles classified under 6 subcategories, which are in turn divided over three broad categories: board of directors, shareholders and disclosure (see Table 2).

Insert Table 2 about here

As you can see from Table 2, our law index differs slightly from our corporate governance index. For instance, our law index only covers three out of the five main categories of our corporate governance index. The reason is that laws are mandatory for every company and that they remain silent on whether or not a company should install different board committees. Hence, our law index does not comprehend the general principles and the principles on board committees. Furthermore, the subcategories of the law index are also slightly different ${ }^{5}$.

\footnotetext{
${ }^{4}$ Not rescaling the scores on the subcategories gives a maximum score of 50 and the same ranking of the countries, except for Germany, who loses the lead to Belgium and shares the second place with France. The results of our analyses are, however, not significantly influenced.

${ }^{5}$ For the board of directors, we combined both the mission and key functions of the board into 1 subcategory called Responsibilities of the board. The number of principles of these subcategories is also reduced from 11 in our corporate governance index to 6 in our law index and we added the principle Fiduciary duty towards shareholders (principle 5). Moreover, compared to the corporate
} 
Again the scoring of this index is straightforward. If the laws of a country prescribe a certain rule, then the score is equal to 1 ; otherwise it is 0 . Once more we employ an equal weighting of the subcategories in the total score by rescaling the score of each subcategory to $1^{6}$. Hence, the maximum obtainable score on the law index is 6 and in the regressions again a percentage score is used. The expectation is that the higher the score of a country, the better shareholders are protected through laws and the more likely companies will adopt IFRS. Therefore, the expected sign for the variable LAW2001 $_{\mathbf{j}}$ is positive.

Further, an interaction variable $\mathbf{C G I}_{\mathbf{j}}{ }^{*} \mathbf{L} \mathbf{A W 2 0 0 1}$, for which a negative coefficient is assumed, is introduced in our model.

Next to the test variables, we include in our regression three country control variables. First of all, we introduce a proxy for the distance between local accounting standards and IFRS (DIST_IFRS j $_{\mathbf{j}}$. We employ the benchmark developed by the big audit firms (Andersen et al., 2001) and described by Street (2002), which gives an overview of the differences between the local standards and IFRS in 62 countries based on approximately 80 accounting measures and disclosures. This variable gives an indication of the number of adjustments an average company has to make in order to comply with IFRS ${ }^{7}$. It is clear that if companies have to make a lot of adaptations to their accounting system, the switch to IFRS will be more costly for them and they will likely postpone the adoption of IFRS. Therefore, a negative sign for this control variable is assumed.

\footnotetext{
governance index, our law index contains 5 extra shareholders principles. We included under the subcategory Shareholders' protection a number of shareholders' rights measured by La Porta et al. (1998) that were not included in our corporate governance index (principles 11, 15, 16, 17 and 18). Next, we added three extra rights of the General Meeting (principles 20, 21 and 24). With regard to the subcategories of disclosure, we did not include the subcategory on timing and that the number of principles included in the two remaining subcategories is severely reduced (from 9 to 2 ).

${ }^{6}$ Not rescaling the scores on the subcategories does neither change the ranking of the countries nor give significantly different results.

${ }^{7}$ A shortcoming of this variable is that it gives an indication of the number of differences between local GAAP and IFRS but not of the significance of these differences. The differences listed may range from absence of an overall standard to a detail of inconsistency (Street, 2002).
} 
Secondly, we include the extent of earnings management at country level $\left(\mathbf{E M}_{\mathbf{j}}\right)$. This variable is developed by Leuz et al. (2003) for 31 countries and is an aggregate score of four different earnings management measurements for the period between 1990 and $1999^{8}$. This variable can be a proxy for the extent to which insiders behave opportunistically in a country. If the level of earnings management is high, insiders can extract a lot of private benefits without being discovered. As under IFRS the possibility to manage earnings, and thus to extract private benefits, is severely reduced, companies in countries with a high level of earnings management have a lower incentive to switch to IFRS. For this variable we thus assume a priori a negative sign.

Finally, we introduce in our model a measure for the size of the capital market, namely the total market capitalization of listed companies as a percentage of GDP $\left(\text { MARKET_CAP }_{\mathbf{j}}\right)^{9}$. On the one hand, strong, well-developed equity markets have usually heavy disclosure requirements (Jaggi and Low, 2000). Thus, the changeover to IFRS would probably be less demanding for companies in broad equity markets. On the other hand, we might also reason that companies in countries with large capital markets will be less likely to adopt IFRS as they have a large potential investor base in their home market so they do not need to use international accounting standards to tap into other markets. So the sign of this variable can not a priori be predicted.

Next to country control variables, we also introduce some company control variables. Firstly, we include company size $\left(\mathbf{S I Z E}_{\mathbf{i}}\right)$ for which a positive sign is expected. Larger companies are more likely to provide stakeholders with more disclosures (Cooke, 1992; Meek and Roberts, 1995; Jaggi and Low, 2000; Ashbaugh, 2001) because of smaller information production costs (Lang and Lundholm, 1993), lower costs of competitive disadvantage associated with their disclosures (Meek and Roberts, 1995) and higher political costs (Foster, 1986). Moreover, large companies also have a broader investor base and thus higher agency costs. The positive link between IFRS and the size of the firm is also evidenced by Ashbaugh (2001) and Dumontier and

\footnotetext{
${ }^{8}$ A country's overall score is computed as the median ratio of the earnings management scores of its companies. The earnings management measurements reflect both the level and variability of the reported earnings. They cover smoothing of reported operating earnings using accruals, smoothing and correlation of accounting accruals and operating cash flow, the magnitude of accruals and small loss avoidance based on Burgstahler and Dichev (1997).

${ }^{9}$ We obtain this data from the World Bank.
} 
Raffournier (1998). We measure the size of a company by the natural logarithm of the total market value $\left(\mathbf{S I Z E}_{\mathbf{i}}\right)$. This variable is preferred above the traditional measurements such as total assets or sales as these are influenced by the accounting standards followed.

A second company control variable is the presence of a big-five auditor $\left(\right.$ AUDITOR $\left._{\mathbf{i}}\right)$. This variable is assumed to have a positive effect on the early adoption of IFRS as large audit firms may stimulate companies to disclose more information (Raffournier, 1995). Big-five audit firms are also more experienced in the application of IFRS (Dumontier and Raffournier, 1998; Murphy, 1999). Dumontier and Raffournier (1998) find evidence that companies audited by a large audit firm are more likely to adopt IFRS voluntarily.

Thirdly, we introduce a variable indicating whether the company is a financial institution or not (FINANCIAL_IND $\mathbf{i}$ ) based on the SIC-codes. We assume that financial institutions were less likely to adopt IFRS in 2001. The reason is that at that point the accounting standards that are particularly aimed at financial institutions, namely IAS 32 and IAS 39, were not endorsed by the EC.

Next, we introduce the variable LISTINGS ${ }_{i}$ which measures the number of listings on a foreign stock exchange. Companies that are listed on foreign stock exchanges face additional capital market pressures for the disclosure of information and have to comply with more stock exchange requirements (Meek and Roberts, 1995; Cuijpers and Buijink, 2004). Thus these companies can be expected to disclose more. The adoption of IFRS will also be more likely for companies listed on multiple stock exchanges as compliance with IFRS can be seen as a form of expanded disclosure specifically aimed at satisfying the needs of foreign users of the financial statements (El-Gazzar et al., 1999). A number of studies find a positive relation between the number of listings of a company and the voluntary adoption of IFRS (Dumontier and Raffournier, 1998; El-Gazzar et al., 1999; Murphy, 1999; Ashbaugh, 2001). 
We also add a measure of ownership concentration (OWNERSHIP ( $\left._{\mathbf{i}}\right)$. This variable is calculated as the ratio of closely held shares (or shares held by insiders) ${ }^{10}$ over common shares outstanding. We hypothesize that as ownership concentration increases, companies will be less likely to adopt IFRS. Insiders to a firm will more likely use other sources of information than the annual report (Cuijpers and Buijink, 2004). Furthermore, companies with large ownership diffusion have higher potential information asymmetries and higher agency costs, and thus higher demands for firmspecific information. As a consequence, they have an incentive to respond to these demands by, for instance, switching to IFRS as this can lower their cost of capital (Raffournier, 1995; Cohen, 2004). We thus expect a negative sign for this variable.

The last company control variable captures the proprietary costs of companies. Models such as Dye (1986) and Hayes and Lundholm (1996) argue that the probability of disclosure decreases as the associated proprietary costs increase. By switching to IFRS, companies have to reveal more proprietary information. Hence, companies with large proprietary costs will probably not adopt IFRS until it becomes mandatory. We include in the regression the variable CAPITAL_INT $\mathbf{i}$ which measure barriers to entry. High capital intensity is generally interpreted as a major barrier of entry (Piotroski, 2003) as new entrants have to make large investments. We measure this variable through net property, plant and equipment scaled by total assets. A lower value of this variable means higher proprietary costs and as a consequence, a lower probability of adopting IFRS before it is mandatory.

An overview of the test and control variables as well as the expected signs can be found in Table 3 .

Insert Table 3 about here

\section{Sample selection and data gathering}

To test the hypotheses developed above, we gather data from two sources. To select the companies and collect financial data, we used the Worldscope database from

\footnotetext{
${ }^{10}$ These include shares held by officers, directors and their immediate family, shares of the company held by another corporation, shares held by pension or benefit plans and shares held by individuals who hold $5 \%$ or more of the outstanding shares.
} 
DATASTREAM. To score countries on the institutional environment (both laws protecting investors laws and corporate governance recommendations), we used the EC's Comparative Study of Corporate Governance Codes (2002).

The sample composition starts with the selection of sample period, namely 2001 . The next step is the selection of all the listed companies from EU stock exchanges that allow the choice between local GAAP and IFRS for domestic and foreign companies in 2001. Our sample thus consists of the companies listed on the stock exchanges of seven EU Member States, namely Austria, Belgium, Denmark, France, Germany, Italy and the Netherlands. In Sweden, Ireland, Portugal, Spain and Greece domestic companies are required to follow local GAAP. In the UK and Luxembourg only foreign companies are allowed to use IFRS and in Finland domestic companies can apply IFRS, but only under specific circumstances ${ }^{11}$. These countries are therefore excluded from the sample. Furthermore, companies listed on the New Market segment of the German Market are also removed from the sample as these companies are obliged to submit their financial statements using either IFRS or US GAAP.

All companies quoted in the year 2001 on these seven stock exchanges and available on Datastream are selected ${ }^{12}$. This results in an initial sample of 2594 listed companies (see Table 4). Of these 2594 companies, 213 or 8\% use IFRS. The following companies are then removed from the sample: companies listed on the German New Market (275), companies reporting according to US GAAP (63), companies with missing data on the control variables $(559)^{13}$ and outliers $(134)^{14}$. A

\footnotetext{
${ }^{11}$ In Finland, domestic listed companies are allowed to follow IFRS (with reconciliation to Finnish GAAP) if more than $50 \%$ of their shares are owned by foreigners or if the company is listed in an OECD country outside the European Economic Area.

${ }^{12}$ We use the total sample of listed companies and not a matched sample because using a matched sample will lead to an overclassification of IFRS-companies and as a result to biased estimators (Zmijewski, 1984). By using in our final sample as many companies as possible from the total population of listed companies, we are able to keep our sample probabilities close to the population probabilities. As a result, our estimates will be likely unbiased and we do not have to use a weighted logit model. Furthermore, Ohlson (1980) contents that there are certain problems related with matching and suggests that it would be more fruitful to include variables as predictors rather than to use them for matching purposes.

${ }^{13}$ Most of the time, data was missing on the variable AUDITOR $_{\mathbf{i}}$, namely for 408 companies no data on the auditors was available. We were not able to hand collect this data as the financial statements of these companies were not available on the websites.

${ }^{14}$ This amounts to about $5.2 \%$ of our initial sample. Most outliers were on the variables SIZE $_{\mathbf{i}}$ and

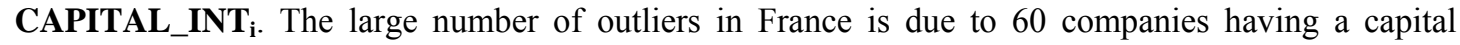
intensity ratio greater than 1 . For these companies the fixed assets are thus larger than the total assets, or in other words, these companies have negative current assets. We deleted these companies.
} 
sample of 1563 companies remains (see Table 4), of which 110 companies (7\%) voluntarily report according to IFRS. We verified from the hard copies that companies following IFRS according to Datastream effectively stated compliance with IFRS in their audit report. Listed companies from France (506) and Germany (396) make up more than half of this sample. Austria and Belgium have the least companies in the sample, 69 and 108 respectively. Most companies following IFRS, namely 64 out of $110(58 \%)$, are located in Germany.

Insert Table 4 about here

Next, we gather data to compute the institutional variables. We rate the countries on the presence of the principles from our two indexes in their corporate governance codes and laws. To this end, we used the Comparative Study of Corporate Governance Codes of all EU countries published by the EC (2002). However, only corporate governance codes that were published before January 2001 were taken into consideration for the computation of our governance index. This means that we measure the extent of corporate governance recommendations at the beginning of our sample period. In Austria, the first corporate governance code was only published at the end of 2002 (Institut Österreichischer Wirtschaftsprüfer, 2002), thus the corporate governance score of Austria is zero. In Belgium and France three codes were published before January 2001, in Germany and the Netherlands two, and in Denmark and Italy only one. The number of codes in a country is indirectly taken into account in the computation of the corporate governance index as a principle should only appear in one of the codes of a country in order for the country to receive a score on that principle. We use the legal system overview in the EC's Comparative Study of Corporate Governance Codes (2002) to score the different countries on our law index.

\section{Univariate and multivariate results}

\subsection{Descriptive statistics and univariate results}

As the main purpose of this paper is to investigate the association between the institutional environment and the decision to adopt IFRS, it is interesting to test first whether a significant relation exists between the countries and the early adoption of IFRS. The $\chi^{2}$-test statistic indicates that a highly significant association $(p<0.0001)$ 
exists between countries and the number of companies reporting according to IFRS. In other words, the number of companies that have adopted IFRS in 2001 depends on the country these companies are domiciled in. Austria and Germany have more companies than expected following IFRS, while the opposite holds for Belgium, Denmark, France, Italy and the Netherlands. Surprisingly, the two countries with more companies following IFRS than expected are both German civil law countries. Hence, differences in the early adoption of IFRS across countries may be attributed to dissimilarities in their institutional environment.

Table 5 gives descriptive statistics of the corporate governance and law index. From Table 5 Panel A, we see that Germany has the highest score on the corporate governance index (0.5251), followed by Belgium (0.4516). On the contrary, Austria has no corporate governance recommendations in 2001. From this table, we can also conclude that, given the maximum percentage score for the corporate governance index is 1 , the extent of corporate governance recommendations could still be increased in all countries, as the mean score of the countries is equal to 0.3464 (i.e. a score of 4.5 on 13). When we investigate the different categories of the corporate governance index, we see that large differences occur between the different countries. For instance, Belgium apparently attaches a lot of value to principles on the board of directors (0.7944), while France focuses on board committees (0.6310). Finally, Germany stresses in its corporate governance codes the importance of shareholders (0.6250) and of disclosure (0.5476).

Insert Table 5 about here

Table 5 Panel B gives an overview of the scoring of the different countries on the law index. Austria has by and large the best legal shareholder protection (0.7540), followed by Germany $(0.5688)$. So the two countries with the most companies following IFRS also have the strongest shareholder protection, either through corporate governance recommendations or through laws. As is the case with the corporate governance index, Germany emphasizes the protection of shareholders in its laws (0.7163). Austria scores the highest on the other two categories, namely board of directors (0.6667) and disclosure (1.0). 
Company descriptives for each country are given in Table 6 Panel A. The companies have on average the same market value in each country, although Danish companies are slightly larger (6.07). Almost all Italian companies have a Big Five auditor (0.95). In contrast, a Big Five auditor is auditing less than one out of two French companies in the sample (0.48). France also has on average the fewest financial institutions (0.12), while Denmark has the most (0.37). Dutch companies are on average listed on more foreign stock exchanges (0.39) and have the highest capital intensity ratio (0.3). Finally, Danish companies are characterised by a low ownership (0.23) compared to the other countries.

Insert Table 6 about here

Table 6 Panel B gives the company descriptives for companies following IFRS or local GAAP separately. Companies that have adopted IFRS early on seem to be on average larger non-financial companies audited by a Big Five auditor and with multiple listings. They also have a lower ownership concentration ratio and have a slightly larger capital intensity ratio. This corresponds to our expectations.

\subsection{Multivariate results}

Different from previous studies (Cuijpers and Buijink, 2004; Dumontier and Raffournier, 1998; El-Gazzar et al., 1999), we do not use a traditional logit model. The correlation tables are shown in Appendix 1 and 2. As we first selected countries for our sample and then companies within each of these countries, we have a clustered dataset. This means that our firm-level observations within a country are more likely to behave in the same way and are as a consequence not independent. The traditional standard error estimates of logistic regression models based on maximum likelihood is no longer appropriate for cluster-correlated data since observations in the same cluster tend to have similar characteristics and are likely correlated with each other. The traditional methods will underestimate the true variance and lead to test statistics with inflated Type I errors. Therefore, a logit model with robust standard errors estimates is needed to take into account the intra-cluster correlation. We will use Rogers standard errors, which are White standard errors adjusted to take into account possible correlation within a cluster (Williams, 2000; Rogers, 1993, Petersen, 2005). 
These clustered robust standard errors control for the within country correlation of the error terms ${ }^{15}$.

The results of the logistic regression with robust standard errors is given in Table $7^{16}$. The pseudo $\mathrm{R}^{2}(31.58 \%)$ indicates that the model is well specified ${ }^{17}$. We find that country characteristics are important for explaining the early adoption of IFRS, as the pseudo $\mathrm{R}^{2}$ of the model without country characteristics only amounts to $5.82 \%$, with all the company variables significant at the $5 \%$ level. The $\mathrm{R}^{2}$ of the model without the company variables amounts to $20.72 \%$ and all variables are highly significant $(\mathrm{p}<$ $0.01)$.

The significance of the individual variables shows that strong laws protecting shareholders (LAW2001 ) $_{\text {) }}$ encourage companies to early comply with IFRS ( $p<$ 0.0001). We also find that corporate governance recommendations $\left(\mathbf{C G I}_{\mathbf{j}}\right)$ are positively associated with the adoption of IFRS $(p<0.0001)$. These results are consistent with our first two hypotheses and indicate that in countries with weak shareholder protection, companies will more likely refrain from adopting IFRS early on due to loss of private benefits.

We run a Wald Chi-square test on the coefficients of our corporate governance and law index to test whether they are significantly different. Surprisingly, we do not find that the coefficients of our indices are significantly different $(p=0.7960)$. This indicates that corporate governance recommendations have an equally strong impact on the adoption of IFRS as laws protecting shareholders. So our third hypothesis does not hold.

Next, we find that the interaction effect between laws and recommendations is significant at the $1 \%$ level $(\mathrm{p}<0.0001)$ and has a negative coefficient. This is

\footnotetext{
${ }^{15}$ Reliance on the Rogers standard errors reduces the estimation error but does not eliminate it as the number of clusters in our paper is rather small $(<10)$ (Petersen, 2005). However, we also performed the regression with dummy variables for the countries (see section 5.3). Our results stayed robust.

${ }^{16}$ The correlation tables are shown in Appendix 1 and 2. The correlation between corporate governance recommendations and laws protecting investors is negative (-0.2984) but not significant. The negative sign could indicate that laws and recommendations are substitutes.

${ }^{17}$ Other studies find pseudo $\mathrm{R}^{2}$ of about 18\% (Ashbaugh, 2001; Cuijpers and Buijink, 2004).
} 
consistent with our fourth hypothesis: in countries with strong corporate governance recommendations but weak laws, companies will adopt IFRS more easily.

We also find some interesting results with regard to the country control variables. For instance, we find that as the distance between local GAAP and IFRS increases, the early adoption of IFRS becomes less likely (DIST_IFRS $\mathbf{j}_{\mathbf{j}}, \mathrm{p}<0.0001$ ). This is consistent with the idea that as the number of accounting changes increase, the adoption of IFRS becomes more costly. Secondly, our results show that more earnings management under local GAAP, measured by $\mathbf{E M}_{\mathbf{j}}$, results in a lower likelihood of applying IFRS $(p<0.0001)$. This is consistent with the notion that companies in countries with a lot of accounting flexibility will try to safeguard their private benefits by postponing the changeover to IFRS. Thirdly, our results indicate that as the size of the capital market increases, companies will stick to their local accounting standards. This indicates that as companies have a larger potential domestic investor base, they have less need to switch to international accounting standards to tap into other markets to obtain enough equity funding (MARKET_CAP, p $<0.0001$ ).

For the company control variables we find that large (SIZE, p $<0.0001)$, nonfinancial (FINANCIAL_IND $\mathbf{i}, \mathrm{p}=0.0003$ ) companies with a Big Five auditor (AUDITOR $_{\mathbf{i}}, \mathrm{p}=0.0013$ ) have a higher rate of early compliance with IFRS. Furthermore, as expected, companies with a low ownership concentration (OWNERSHIP, OW $\left._{i}=0.007\right)$ will adopt IFRS before it is mandatory. However, contrarily to previous studies, we do not find that the number of listings (LISTINGS $\mathrm{p}=0.393)$ is an important explanatory variable. Finally, the level of proprietary costs does not seem to have an influence on IFRS-adoption (CAPITAL_INT $\mathbf{i}, \mathbf{p}=0.380$ ).

Insert Table 7 about here

As an extension of the basic model, different categories of the corporate governance index (general principles, board of directors, board committees, shareholders' rights and disclosure) are separately introduced in the model. For each category that is introduced in the analysis, we also include an interaction variable with the law index (see Table 8). The same analysis is repeated for the categories of the law index. Each element (board of directors, shareholders' rights and disclosure) is separately included 
as well as the interaction with the corporate governance index (see Table 9). We find, for our corporate governance index, that strong recommendations with regard to the board of directors, the board committees and disclosure encourage the adoption of IFRS. Surprisingly, extensive recommendations with respect to shareholders seem to have no impact on the likelihood of adopting IFRS. Concerning the subcategories of our law index, we find that all three subcategories, namely board of directors, shareholders and disclosure, are positively related with the early adoption of IFRS. This seems to suggest that the protection of shareholders' rights can only be achieved through hard laws. In other words, corporate governance recommendations can not substitute completely for laws. There are still some areas in which mandatory investor protection is needed.

Insert table 8 and 9 about here

\subsection{Sensitivity analyses}

Some sensitivity checks are first done with respect to the country variables. Firstly, the large number of French and German companies in the sample could suggest that these two countries strongly influence our results. So the logistic regressions are rerun excluding these two countries and the results stay similar.

Secondly, Austria and Germany are excluded from the sample as these are the countries with the largest number IFRS-companies. This reduces the number of companies following IFRS in the final sample to 21. Although this number seems rather low, the proportion of companies following IFRS in the final sample, excluding Austria and Germany, is just slightly above the proportion of companies following IFRS in the initial sample, excluding the same countries. Hence our regression results will not be biased (Zmijewski, 1984). Excluding Austria and Germany from the sample does not significantly alter our results much.

Thirdly, we run regressions with a dummy-variable for Germany and Austria. This dummy-variable then captures that Austria and Germany are environments in which companies are stimulated more to adopt IFRS. The dummy variable is significantly positive at the $1 \%$-level, indicating that companies from Germany and Austria are more likely to adopt IFRS early on. The coefficients of the other variables are not 
significantly influenced by including this dummy-variable. We can thus conclude that our results are not driven by the composition of our sample.

Finally, we run regressions without the country variables but with 6 dummy variables for the countries. We used Germany as our base-country. We find that, compared to Germany, only Austria has a positive impact on IFRS-adoption. Italy has the most negative impact on IFRS-adoption.

Some sensitivity checks are also performed for the company control variables. Firstly, the size of a company is alternatively measured by the natural logarithm of total assets and of sales. These alternative specifications do not change our results. The number of listings is also specified differently. We measured this variable alternatively as a dummy variable indicating whether or not a company is listed on another stock exchange that allows the use of IFRS. We also measured this variable as a dummy variable indicating whether or not a company is listed on a stock exchange outside the EU. The $p$-value is the lowest and becomes marginally significant $(p=0.0966)$ for the variable measuring a listing outside the EU.

\section{Conclusion}

The purpose of this paper is to explain the early adoption of IFRS from a cost-side perspective. As IFRS-adoption is associated with an increase in disclosure and a reduction in accounting choices, it leads to less managerial discretion and a loss of private benefits for insiders. In this study, we argue that the private benefits insiders have to give up by adopting IFRS depend on the characteristics of the institutional environment. We investigate, besides the level of legal investor protection, also a characteristic of the institutional environment not yet studied, namely the extent of corporate governance recommendations.

Our results suggest that IFRS-adoption depends on the level of investor protection. Companies will refrain from adopting IFRS early on because of opportunistic behaviour by management in countries with weak investor protection. In these countries, the costs of adopting IFRS are perceived by the company insiders as higher due losses of private benefits. Strong laws protecting investors as well as extended corporate governance recommendation in contrast lower private benefits of control, 
thereby reducing the costs of switching to IFRS for insiders. Furthermore, we find that corporate governance recommendations have the same impact on IFRS-adoption as hard laws and are able to compensate for the negative impact of weak laws. In other words, corporate governance can effectively reduce the potential conflict of interest between insiders and outsiders. However, we find that this is not true in case specific shareholder rights, such as voting rights and rights of the general meeting. In this case, laws are needed in order to effectively constrain the extraction of private benefits.

A caveat of this study certainly is that the countries used in our sample are all civil law countries. A more extended study, using a wider variety of countries which differ more in terms of economic development and level of regulation, would certainly be interesting. 


\section{Appendix 1: Pearson Correlation Coefficients for the Country Variables}

$\mathrm{N}=7$, Prob $>|\mathrm{r}|$ under $\mathrm{H}_{0}: \rho=0$

\begin{tabular}{lrrrrr}
\hline & LAW2001 $_{\mathbf{j}}$ & CGI $_{\mathbf{j}}$ & DIST_IFRS $_{\mathbf{j}}$ & EM $_{\mathbf{j}}$ & MARKET_CAP $_{\mathbf{j}}$ \\
\hline \hline LAW2001 $_{\mathbf{j}}$ & 1 & & & & \\
CGI $_{\mathbf{j}}$ & -0.2984 & 1 & & & \\
DIST_IFRS $_{\mathbf{j}}$ & $0.7413^{*}$ & 0.0775 & 1 & & 1 \\
EM $_{\mathrm{j}}$ & $0.7814^{*}$ & -0.3068 & 0.5982 & 1 & \\
MARKET_CAP $_{\mathbf{j}}$ & $-0.8250^{*}$ & 0.0732 & $-0.7054^{*}$ & -0.7522 & \\
\hline \multicolumn{6}{c}{ * significant at the $5 \%$ level }
\end{tabular}

Appendix 2: Pearson Correlation Coefficients for the Company Variables $\mathrm{N}=1563$, Prob $>|\mathrm{r}|$ under $\mathrm{H}_{0}: \rho=0$

\begin{tabular}{|c|c|c|c|c|c|c|}
\hline & SIZE $_{i}$ & AUDITOR $_{i}$ & FINANCIAL_IND & LISTINGS $_{\mathrm{i}}$ & OWNERSHIP $_{i}$ & CAPITAL_INT ${ }_{i}$ \\
\hline SIZE $_{i}$ & 1 & & & & & \\
\hline AUDITOR $_{\mathbf{i}}$ & $0.3262^{\star}$ & 1 & & & & \\
\hline FINANCIAL_IND & $0.1223^{\star}$ & 0.0604 & 1 & & & \\
\hline LISTINGS $_{\mathrm{i}}$ & $0.3413^{\star}$ & $0.1130^{*}$ & 0.0109 & 1 & & \\
\hline OWNERSHIP $_{\mathrm{i}}$ & 0.0363 & -0.0117 & 0.0038 & -0.0754 & 1 & \\
\hline CAPITAL_INT ${ }_{i}$ & $0.0496^{*}$ & $\begin{array}{r}0.0229 \\
*\end{array}$ & $\begin{array}{l}-0.1223^{*} \\
\text { nificant at the } 5 \% \text { le }\end{array}$ & 0.0012 & 0.0768 & 1 \\
\hline
\end{tabular}

We computed the Variance Inflation Factors (VIFs) in order to search for problems of multicollinearity. The VIFs are all below 2.40 for the company variables (highest VIF $=2.32$ for SIZE $_{\mathbf{i}}$ ) and below 7.50 for the country variables (highest VIF $=7.45$ for $\mathbf{L A W 2 0 0 1}_{\mathbf{j}}$ ). So no problems of multicollinearity will arise in our regressions as the VIFs are smaller than 10. 


\section{References}

Andersen, BDO, Deloitte Touche Tohmatsu, Ernst\&Young, Grant Thornton, KPMG and PriceWaterhouseCoopers (2001) GAAP 2001: A Survey of National Accounting Rules Benchmarked Against International Account Standards, available from http://www.pwcglobal.com, p. 74.

Ashbaugh H. (2001) Non-US Firms' Accounting Standards Choice, Journal of Accounting and Public Policy, 20 (2), 129-153.

Black B. (2001) Does Corporate Governance Matter: A Crude Test Using Russian Data, University of Pennsylvania Law Review, 149 (6), 2131-2150.

Burgstahler D. and Dichev I. (1997) Earnings Management to Avoid Earnings Decreases and Losses, Journal of Accounting and Economics, 24 (1), 99-129.

Coffee J. (2001) Do Norms matter? A Cross-Country Examination of the Private Benefits of Control, Columbia Law School Working Paper No. 183, p. 30.

Cohen D. (2004) Quality of Financial Reporting Choice: Determinants and Economic Consequences, Working paper, Northwestern University, p. 66.

Cooke T. (1992) The Impact of Size, Stock Market Listing and Industry Type on Disclosure in the Annual Reports of Japanese Listed Corporations, Accounting and Business Research, 22 (87), 229-237.

Council of the EC (1978) Fourth Council Directive 78/660/EEC of 25 July 1978 based on Article 54 (3) (g) of the Treaty on the Annual Accounts of Certain Types of Companies, Document 378L0660, Official Journal L 220, p. 0011-0031.

Council of the EC (1983) Seventh Council Directive 83/349/EEC of 13 June 1983 based on the Article 54 (3) (g) of the Treaty on Consolidated Accounts, Document 383L0349, Official Journal L 193, p. 0001-0017.

Cuijpers R. and Buijink W. (2004) Voluntary adoption of Non-local GAAP in the European Union: a Study of Determinants and Consequences, Working Paper, Forthcoming European Accounting Review, p. 52. 
Dumontier P. and Raffournier B. (1998) Why Firms Comply Voluntarily with IAS: an Empirical Analysis with Swiss Data, Journal of International Financial Management and Accounting, 9 (3), 216-245.

Dyck A. and Zingales L. (2004) Private Benefits of Control: an International Comparison, Journal of Finance, 59 (2), 537-600.

Dye, R. (1986) Proprietary and Nonproprietary Disclosures, Journal of Business, 59 (2), 331-366.

El-Gazzar S., Finn P. and Jacob R. (1999) An Empirical Investigation of Multinational Firms' Compliance with International Accounting Standards, The International Journal of Accounting, 34 (2), 239-248.

European Commission (2000) Communication from the Commission to the Council and the European Parliament: EU Financial Reporting Strategy: the Way Forward, COM(2000) 359 final, p. 10.

European Commission (2002) Comparative Study of Corporate Governance Codes Relevant to the European Union and its Member States, available from http://www.europa.eu.int/comm/internal_market/en/company/news/corp_gov_codes, p. 370 .

Ferrell A. (2004) The Case for Mandatory Disclosure in Securities Regulation around the World, Harvard John M. Olin Discussion Paper Series 10/2004, Cambridge, p. 63.

Foster G. (1986) Financial Statement Analysis, $2^{\text {nd }}$ Edition, Prentice-Hall.

Hayes R. and Lundholm R. (1996) Segment Reporting to the Capital Market in the Presence of a Competitor, Journal of Accounting Research, 34 (2), 261-279.

Institut Österreichischer Wirtschaftsprüfer (IWP) (September 2002) Österreichischer Corporate Governance Code, available from http://www.iwp.or.at, p. 37. 
Jaggi B. and Low P. (2000) Impact of Culture, Market Forces, and Legal System on Financial Disclosures, The International Journal of Accounting, 35 (4), 495-519.

La Porta R., Lopez-de-Silanes F., Shleifer A. and Vishny A. (1998) Law and Finance, Journal of Political Economy, 106 (6), 1113-1155.

La Porta R., Lopez-de-Silanes F. and Shleifer A. (2004) What Works in Securities Laws?, Working Paper, Darthmouth College, p. 44.

Lang M. and Lundholm R. (1993) Cross-sectional Determinants of Analyst Ratings of Corporate Disclosures, Journal of Accounting Research, 31 (2), 246-271.

Leuz C., Nanda D. and Wysocki P. (2003) Earnings Management and Investor Protection: an International Comparison, Journal of Financial Economics, 69 (3), 505-527.

Leuz C. and Verrecchia R. (2000) The Economic Consequences of Increased Disclosure, Journal of Accounting Research, 38 suppl., 91-124.

Licht A. (2003) Cross-listing and Corporate Governance: Bonding or Avoiding? Working Paper, Harvard Law School, Tel Aviv University, p. 34.

Meek G. and Roberts C. (1995) Factors Influencing Voluntary Annual Report Disclosures by U.S., U.K. and Continental European Multinational Corporations, Journal of International Business Studies, 26 (3), 555-573.

Murphy A. (1999) Firm Characteristics of Swiss Companies that Utilize International Accounting Standards, The International Journal of Accounting, 34 (1), 21-131.

Nenova T. (2003) The Value of Corporate Voting Rights and Control: A CrossCountry Analysis, Journal of Financial Economics, 68 (3), 325-351.

Organisation for Economic Co-operation and Development (OECD) (1999) OECD Principles of Corporate Governance, available from http://www.oecd.org, p. 25.

Ohlson J. (1980) Financial Ratios and the Probabilistic Prediction of Bankruptcy, Journal of Accounting Research, 18 (1), 109-131. 
Petersen M. (2005) Estimating Standard Errors in Finance Panel Data Sets: Comparing Approaches, Working Paper, Kellogg School of Management, Northwestern University, p. 63.

Piotroski J. (2003) Segment Reporting Fineness and the Precision of Investors Beliefs, Working paper, University of Chicago.

PriceWaterhouseCoopers (2002) 2005- Ready or Not: IAS in Europe - the Views of over 650 CFOs, available from http://www.pwcglobal.com/ias, p. 32.

Raffournier B. (1995) The Determinants of Voluntary Financial Disclosure by Swiss Listed Companies, The European Accounting Review, 4 (2), 261-280.

Rogers W. (1993) Regression Standard Errors in Clustered Samples, Stata Technical Bulletin, 13, 19-23.

Street D. (2002) GAAP 2001 - Benchmarking National Accounting Standards against IAS: Summary of Results, Journal of International Accounting, Auditing and Taxation, 11 (1), 77-90.

Williams R. (2000) A Note on Robust Variance Estimation for Cluster-Correlated Data, Biometrics, 56 (2), 645-646.

Zmijewski M. (1984) Methodological Issues Related to the Estimation of Financial Distress Prediction Models, Journal of Accounting Research, vol. 22 suppl., 59-82. 


\section{Table 1: Structure of the Corporate Governance Index $\left(\mathrm{CGI}_{\mathbf{j}}\right)$}

\section{GENERAL PRINCIPLES}

I. Legal basis and compliance (1)

1. Comply-or-explain principle $\quad$ Yes / No

II. Scope (1)

2. Encouraged to all companies

Yes / No

\section{BOARD OF DIRECTORS}

III. Mission of the board (5)

3. Shareholder value maximization

Yes / No

4. Long-term viability of the company

Yes / No

5. Good relationship with stakeholders

Yes / No

6. Effective monitoring of management

Yes / No

7. Compliance with laws

Yes / No

IV. Key functions of the board (6)

8. Guide corporate strategy

Yes / No

9. Monitor and replace key executives

Yes / No

10. Review remuneration

Yes / No

11. Manage potential conflicts of interest

Yes / No

12. Guard integrity of financial reporting

Yes / No

13. Increase effectiveness of governance practices

Yes / No

V. Independence of the board (3)

14. Separation of chairman and CEO

Yes / No

15. Mix of inside and outside directors

Non-executive directors

None I minimum number I majority

Independent directors None / minimum number / majority

16. Stock options not allowed as compensation

Yes / No

\section{BOARD COMMITTEES}

\section{Recommended committees (3)}

17. Appointment committee

18. Remuneration committee

19. Audit committee

VII. Key functions of the committees (7)

20. Appointment committee: propose appointment of directors

21. Remuneration committee: recommend remuneration for directors

22. Audit committee: report to the board

23. Audit committee: hear the company auditors

24. Audit committee: ensure appropriateness and consistency of accounting policies

25. Audit committee: verify accuracy of internal procedures

26. Audit committee: appoint auditor and determine audit fee

VIII. Independence of the committees (6)

27. Appointment committee: non-executive directors

28. Appointment committee: independent directors

29. Remuneration committee: non-executive directors

30. Remuneration committee: independent directors

31. Audit committee: non-executive directors

32. Audit committee: independent directors
Yes / No
Yes / No
Yes / No
Yes / No
Yes / No
Yes / No
Yes / No
Yes / No
Yes / No
Yes / No

\begin{abstract}
None / minimum number / majority None / minimum number / majority None / minimum number / majority None / minimum number / majority None I minimum number / majority None / minimum number / majority
\end{abstract}


Table 1 (continued): Structure of the Corporate Governance Index (CGI $\left.\mathbf{C}_{\mathbf{j}}\right)$

\section{SHAREHOLDERS}

IX. Shareholders' protection (4)

33. Equal treatment of shareholders

Yes / No

34. One share/one vote

Yes / No

35. No anti-take-over devices

Yes / No

36. Proxy voting allowed

Yes / No

X. General meeting (4)

37. Select new directors

Yes / No

38. Participate in decisions concerning fundamental changes

Yes / No

39. Decide on distribution of profits

Yes / No

40. Ask questions

Yes / No

\section{DISCLOSURE}

XI. Quality (2)

41. Use high quality accounting standards

Yes / No

42. Audited by an independent auditor

Yes / No

XII. Timing (1)

43. Timely disclosure of relevant information

Yes / No

XIII. Contents (7)

44. Financial situation

Yes / No

45. Performance

Yes / No

46. Ownership

Yes / No

47. Governance

Yes / No

48. Relevant interests of directors

Yes / No

49. Composition of the board

Yes / No

50. Remuneration of key executives

Yes / No

TOTAL

"The numbers between brackets indicate the number of principles in each subcategory. 
Table 2: Structure of the Law Index (LAW2001 j $_{\text {) }}$

\begin{tabular}{ll}
\hline \hline BOARD OF DIRECTORS & \\
\hline I. Responsibilities of the board (6) & \\
1. Probity of financial statements & Yes / No \\
2. Monitor management & Yes / No \\
3. Guide corporate strategy & Yes / No \\
4. Guard compliance with laws and regulations & Yes / No \\
5. Fiduciary duty towards shareholders & Yes / No \\
6. Avoid conflicts of interests & Yes / No \\
II. Independence of the board (3) & \\
7. Separation of chairman and CEO & Yes / No \\
8. Non-executive directors & Yes / No \\
9. Independent directors & Yes / No \\
\hline SHAREHOLDERS & \\
\hline III. Shareholders' protection (9) & \\
10. Proxy voting allowed & \\
11. Pre-emptive right to new issues & Yes / No \\
12. One share/one vote & Yes / No \\
13. Equal treatment of shareholders & Yes / No \\
14. Anti-takeover devices prohibited & Yes / No \\
15. Shares not blocked before meeting & Yes / No \\
16. Cumulative voting allowed & Yes / No \\
17. Oppressed minorities mechanism installed & Yes / No \\
18. Percentage needed to call an extraordinary GM & Yes / No \\
\hline IV. General Meeting (7) & Yes / No \\
19. Ask questions & \\
20. Submit proposals & Yes / No \\
21. Decide on remuneration of directors & \\
22. Select directors & Yes / No \\
23. Decide on distribution of profits & Yes / No \\
24. Appoint statutory auditor & Yes / No \\
25. Agree on fundamental changes & Yes / No \\
DISCLOSURE & Yes / No \\
\hline V. Quality (1) & Yes / No \\
26. Audited by an independent auditor & Yes / No \\
VI. Contents (1) & \\
27. Remuneration & \\
\hline \hline TOTAL & \\
\hline
\end{tabular}

\section{TOTAL}

*The numbers between brackets indicate the number of principles in each subcategory. 
Table 3: Overview of the Variables Included in the Model

\begin{tabular}{|c|c|c|}
\hline & Definition & Expected sign \\
\hline \multicolumn{3}{|l|}{ With dependent variable } \\
\hline IFRS $_{i j}$ & $\begin{array}{l}=1 \text { if company } \mathrm{i} \text { in country } \mathrm{j} \text { follows IFRS in } 2001,0 \\
\text { otherwise }\end{array}$ & \\
\hline \multicolumn{3}{|l|}{ With test variables } \\
\hline LAW2001 & $\begin{array}{l}=\text { Extent of laws protecting shareholders within } \\
\text { country j in } 2001\end{array}$ & + \\
\hline $\mathrm{CGI}_{\mathrm{j}}$ & $\begin{array}{l}=\text { Extent of corporate governance recommendations } \\
\text { within country } \mathrm{j} \text { in } 2001\end{array}$ & + \\
\hline $\mathrm{CGI}_{\mathrm{i}}^{*} \mathrm{LAW} 2001_{\mathrm{i}}$ & $\begin{array}{l}=\text { Interaction term between extent of corporate } \\
\text { governance recommendations and extent of laws }\end{array}$ & - \\
\hline \multicolumn{3}{|l|}{ With country control variables } \\
\hline DIST_IFRS $_{\mathrm{j}}$ & $\begin{array}{l}\text { = Distance between local GAAP and IFRS based on } \\
90 \text { accounting measures and disclosures as } \\
\text { measured by Street (2002) }\end{array}$ & - \\
\hline$E M_{j}$ & $\begin{array}{l}=\text { Degree of earnings management as measured by } \\
\text { Leuz et al. (2002) }\end{array}$ & - \\
\hline MARKET_CAP & $\begin{array}{l}=\text { Total market capitalisation of the listed companies } \\
\text { in country j in } 2001 \text { (Worldbank) }\end{array}$ & $?$ \\
\hline \multicolumn{3}{|l|}{ With company control variables } \\
\hline $\mathrm{SIZE}_{\mathrm{i}}$ & $\begin{array}{l}\text { = Company size measured by the natural logarithm of } \\
\text { total market value (Datastream) }\end{array}$ & + \\
\hline AUDITOR $_{\mathrm{i}}$ & $\begin{array}{l}=1 \text { if company } \mathrm{i} \text { has a big-five auditor, } 0 \text { otherwise } \\
\text { (Datastream) }\end{array}$ & + \\
\hline FINANCIAL_IND ${ }_{i}$ & $\begin{array}{l}=1 \text { if company } \mathrm{i} \text { is a financial institution, } 0 \text { otherwise, } \\
\text { based on the two-digit SIC-code (Datastream) }\end{array}$ & - \\
\hline LISTINGS & $\begin{array}{l}=\text { Number of listings on a foreign stock exchange } \\
\text { (Datastream) }\end{array}$ & + \\
\hline OWNERSHIP $_{\mathrm{i}}$ & $\begin{array}{l}=\text { Ratio of closely held shares over common shares } \\
\text { outstanding in } 2001 \text { (Datastream) }\end{array}$ & - \\
\hline CAPITAL_INT & $\begin{array}{l}\text { = Ratio of fixed assets over total assets in } 2001 \\
\text { (Datastream) }\end{array}$ & + \\
\hline
\end{tabular}

Table 4: Sample Selection

\begin{tabular}{|c|c|c|c|c|c|c|c|c|}
\hline & Austria & Belgium & Denmark & France & Germany & Italy & Netherlands & Total \\
\hline \multicolumn{9}{|l|}{ All listed companies in } \\
\hline \multirow[t]{2}{*}{ Datastream $\$$} & 89 & 139 & 175 & 833 & 942 & 260 & 156 & 2594 \\
\hline & 29 & 5 & 8 & 4 & 162 & 2 & 3 & 213 \\
\hline Of which following IFRS & $(32.6 \%)$ & $(3.6 \%)$ & $(4.6 \%)$ & $(0.5 \%)$ & $(17.2 \%)$ & $(0.8 \%)$ & $(1.9 \%)$ & $(8.2 \%)$ \\
\hline \multicolumn{9}{|l|}{ MINUS } \\
\hline - German New Market listings & $(0)$ & (0) & $(0)$ & $(0)$ & $(275)$ & (0) & (0) & $(275)$ \\
\hline - companies using US GAAP & (6) & (3) & (0) & (10) & (37) & $(0)$ & (7) & (63) \\
\hline - Missing values & (10) & (24) & $(23)$ & (239) & (201) & $(48)$ & (14) & $(559)$ \\
\hline \multirow[t]{2}{*}{ - Outliers } & (4) & (4) & (8) & $(78)^{\#}$ & $(33)$ & (4) & (3) & (134) \\
\hline & 69 & 108 & 144 & 506 & 396 & 208 & 132 & 1563 \\
\hline \multirow[t]{2}{*}{ Final sample } & $(77.5 \%)$ & $(77.7 \%)$ & $(82.3 \%)$ & $(60.7 \%)$ & $(42.0 \%)$ & $(80.0 \%)$ & $(84.6 \%)$ & $(60.3 \%)$ \\
\hline & 25 & 5 & 8 & 4 & 64 & 1 & 3 & 110 \\
\hline \multirow[t]{2}{*}{ - Companies using IFRS } & $(36.2 \%)$ & $(4.6 \%)$ & $(5.6 \%)$ & $(0.8 \%)$ & $(16.2 \%)$ & $(0.5 \%)$ & $(2.3 \%)$ & $(7 \%)$ \\
\hline & 44 & 103 & 136 & 502 & 332 & 207 & 129 & 1453 \\
\hline - Companies using local GAAP & $(63.8 \%)$ & $(95.4 \%)$ & $(94.4)$ & $(99.2 \%)$ & $(83.8 \%)$ & $(99.5 \%)$ & $(97.7 \%)$ & $(93 \%)$ \\
\hline
\end{tabular}

${ }^{S}$ Datastream coverage for our sample countries varies between $88 \%$ for Denmark and $99 \%$ for the Netherlands. The average coverage ratio for the 7 countries is $94.6 \%$.

${ }^{\#} 60$ companies of these 78 were deleted because of a capital intensity ratio higher than 1 , which means that the fixed assets of these companies are larger than the total assets. In other words, these companies have negative current assets. 
Table 5 Panel A: Scoring of the Corporate Governance Index (CGI $)$

\begin{tabular}{|c|c|c|c|c|c|c|c|}
\hline & 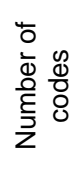 & 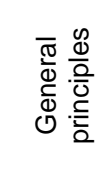 & 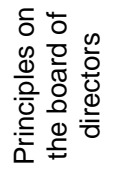 & 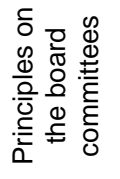 & 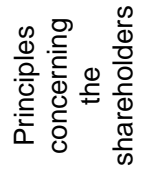 & 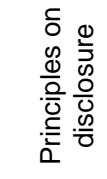 & TOTAL \\
\hline Austria & 0 & 0.0 & 0.0000 & 0.0000 & 0.0000 & 0.0000 & 0.0000 \\
\hline Belgium & 3 & 0.5 & 0.7944 & 0.3770 & 0.2500 & 0.2857 & 0.4517 \\
\hline Denmark & 1 & 0.0 & 0.2333 & 0.4286 & 0.5000 & 0.0476 & 0.2407 \\
\hline France & 3 & 0.0 & 0.4333 & 0.6310 & 0.3750 & 0.0952 & 0.3253 \\
\hline Germany & 2 & 0.5 & 0.4778 & 0.5000 & 0.6250 & 0.5476 & 0.5251 \\
\hline Italy & 1 & 0.5 & 0.3444 & 0.4563 & 0.1250 & 0.0952 & 0.03029 \\
\hline Netherlands & 2 & 0.0 & 0.4778 & 0.0000 & 0.2500 & 0.0952 & 0.1707 \\
\hline Mean & 1.71 & 0.2278 & 0.4239 & 0.4572 & 0.3808 & 0.2144 & 0.3464 \\
\hline Median & 2.00 & 0.0000 & 0.4333 & 0.5000 & 0.3750 & 0.0952 & 0.3253 \\
\hline $\operatorname{Max}$ & 3.00 & 0.5000 & 0.7944 & 0.6310 & 0.6250 & 0.5476 & 0.5251 \\
\hline Min & 0.00 & 0.0000 & 0.0000 & 0.0000 & 0.0000 & 0.0000 & 0.0000 \\
\hline Std Dev & 1.11 & 0.2491 & 0.1504 & 0.1941 & 0.1849 & 0.2020 & 0.1349 \\
\hline Q1 & 1.00 & 0.0000 & 0.3444 & 0.4286 & 0.2500 & 0.0952 & 0.3029 \\
\hline Q3 & 3.00 & 0.5000 & 0.4778 & 0.6310 & 0.6250 & 0.5476 & 0.5251 \\
\hline
\end{tabular}

Table 5 Panel B: Scoring of the Law Index (LAW2001 $)_{j}$

\begin{tabular}{|c|c|c|c|c|}
\hline & 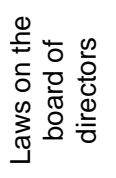 & 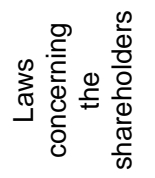 & 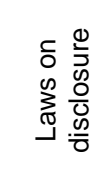 & TOTAL \\
\hline Austria & 0.6667 & 0.5952 & 1.0 & 0.7540 \\
\hline Belgium & 0.4167 & 0.4127 & 0.0 & 0.2765 \\
\hline Denmark & 0.5000 & 0.4524 & 0.0 & 0.3175 \\
\hline France & 0.5000 & 0.5952 & 0.0 & 0.3651 \\
\hline Germany & 0.5000 & 0.7063 & 0.5 & 0.5688 \\
\hline Italy & 0.5000 & 0.5794 & 0.5 & 0.5265 \\
\hline Netherlands & 0.3333 & 0.3810 & 0.0 & 0.2381 \\
\hline Mean & 0.4875 & 0.5774 & 0.2374 & 0.4341 \\
\hline Median & 0.5000 & 0.5952 & 0.0000 & 0.3651 \\
\hline Max & 0.6667 & 0.7063 & 1.0000 & 0.7540 \\
\hline Min & 0.3333 & 0.3810 & 0.0000 & 0.2381 \\
\hline Std Dev & 0.0624 & 0.1045 & 0.2906 & 0.1342 \\
\hline Q1 & 0.5000 & 0.5794 & 0.0000 & 0.3651 \\
\hline Q3 & 0.5000 & 0.7063 & 0.5000 & 0.5688 \\
\hline
\end{tabular}


Table 6 Panel A: Descriptives of Company Variables per Country

\begin{tabular}{|c|c|c|c|c|c|c|c|}
\hline & $\mathbf{N}$ & SIZE $_{i}$ & AUDITOR $_{\mathrm{i}}$ & FINANICIAL_IND $_{\mathrm{i}}$ & LISTINGS $_{\mathrm{i}}$ & OWNERSHIP $_{\mathrm{i}}$ & CAPITAL_INT \\
\hline Austria & 69 & 4.2089 & 0.6377 & 0.3333 & 0.0580 & 0.3450 & 0.2845 \\
\hline Belgium & 108 & 5.0229 & 0.5926 & 0.2870 & 0.2222 & 0.4081 & 0.2572 \\
\hline Denmark & 144 & 6.0746 & 0.8750 & 0.3681 & 0.0556 & 0.2332 & 0.2425 \\
\hline France & 506 & 4.6813 & 0.4842 & 0.1225 & 0.0949 & 0.4399 & 0.1760 \\
\hline Germany & 396 & 4.5965 & 0.5884 & 0.2374 & 0.2071 & 0.4650 & 0.2868 \\
\hline Italy & 208 & 5.8627 & 0.9519 & 0.2644 & 0.2067 & 0.4442 & 0.2019 \\
\hline Netherlands & 132 & 5.3932 & 0.9015 & 0.1742 & 0.3939 & 0.3309 & 0.3000 \\
\hline Mean & 226.86 & 5.0083 & 0.6583 & 0.2182 & 0.1670 & 0.4122 & 0.2345 \\
\hline Median & 147.00 & 4.8283 & 1.0000 & 0.0000 & 0.0000 & 0.4741 & 0.1686 \\
\hline Max & 514.00 & 11.6841 & 1.0000 & 1.0000 & 10.0000 & 0.9887 & 0.9925 \\
\hline Min & 69.00 & 0.3001 & 0.0000 & 0.0000 & 0.0000 & 0.0000 & 0.0000 \\
\hline St Dev & 167.09 & 2.1142 & 0.4744 & 0.4131 & 0.8615 & 0.3246 & 0.2314 \\
\hline Q1 & 121.50 & 3.5041 & 0.0000 & 0.0000 & 0.0000 & 0.0000 & 0.0343 \\
\hline Q3 & 307.50 & 6.2885 & 1.0000 & 0.0000 & 0.0000 & 0.6881 & 0.3603 \\
\hline
\end{tabular}

Table 6 Panel B: Descriptives of Company Variables for IFRS and local GAAP

\begin{tabular}{ccc}
\hline & IFRS & Local GAAP \\
\hline \hline $\mathbf{N}$ & 110 & 1453 \\
SIZE $_{\mathbf{i}}$ & 5.9178 & 4.9394 \\
AUDITOR & 0.8091 & 0.6469 \\
FINANICIAL_IND & 0.1454 & 0.2237 \\
LISTINGS $_{\mathbf{i}}$ & 0.5727 & 0.1363 \\
OWNERSHIP $_{\mathbf{i}}$ & 0.3535 & 0.4166 \\
CAPITAL_INT $_{\mathbf{i}}$ & 0.2796 & 0.2311 \\
\hline \hline
\end{tabular}


Table 7: Results of the Logistic Regression

${ }^{* * *}$ significant at $1 \%$ level, ${ }^{* *}$ significant at $5 \%$ level, ${ }^{*}$ significant at the $10 \%$ level

\begin{tabular}{lccc}
\hline Parameter & Estimate & $\begin{array}{c}\text { Robust } \\
\text { Std Error }\end{array}$ & Pr $>$ ChiSq \\
\hline Intercept & -0.837 & 0.621 & 0.178 \\
Test variables & & & \\
LAW2001 $_{\mathrm{j}}$ & 55.144 & 1.245 & $<.0001^{\text {*** }}$ \\
CGI $_{\mathrm{j}}$ & 54.425 & 1.348 & $<.0001^{\text {*** }}$ \\
CGI $_{\mathrm{j}}^{*}$ LAW2001 $_{\mathrm{j}}$ & -83.686 & 2.023 & $<.0001^{\text {*** }}$ \\
Country control variables & & & \\
DIST_IFRS $_{\mathrm{j}}$ & -0.704 & 0.013 & $<.0001^{\text {*** }}$ \\
EM $_{\mathrm{j}}$ & -0.572 & 0.009 & $<.0001^{\text {*** }}$ \\
MARKET_CAP $_{\mathrm{j}}$ & -0.078 & 0.003 & $<.0001^{\text {*** }}$ \\
Company control variables & & & \\
SIZE $_{\mathrm{i}}$ & 0.356 & 0.061 & $<.0001^{\text {*** }}$ \\
AUDITOR $_{\mathrm{i}}$ & 0.914 & 0.203 & $0.0013^{\text {*** }}$ \\
FINANCIAL_IND $_{\mathrm{i}}$ & -1.196 & 0.230 & $0.0003^{\text {*** }}$ \\
LISTINGS $_{\mathrm{i}}$ & 0.052 & 0.061 & 0.393 \\
OWNERSHIP $_{\mathrm{i}}$ & -0.944 & 0.350 & $0.007^{*+*}$ \\
CAPITAL_INT $_{\mathrm{i}}$ & -0.200 & 0.228 & 0.380 \\
\hline
\end{tabular}

$\mathrm{R}^{2}=31.58 \%$ 
Table 8: Results of the Logistic Regression with the Categories of CGI.

${ }^{* * *}$ significant at $1 \%$ level, ${ }^{* *}$ significant at $5 \%$ level, ${ }^{*}$ significant at $10 \%$ level $\mathrm{N}=1563$

\begin{tabular}{|c|c|c|c|c|c|c|c|c|c|c|}
\hline Parameter & Estimate & $\mathrm{Pr}>\mathrm{ChiSq}$ & Estimate & $\mathrm{Pr}>\mathrm{ChiSq}$ & Estimate & $\mathrm{Pr}>\mathrm{ChiSq}$ & Estimate & $\mathrm{Pr}>\mathrm{ChiSq}$ & Estimate & $\mathrm{Pr}>\mathrm{ChiSq}$ \\
\hline Intercept & 17.7605 & 0.0004 & 11.1337 & 0.0048 & 28.4993 & $<.0001$ & 26.1900 & $<.0001$ & 11.3169 & $<.0001$ \\
\hline CG_GENERAL & 39.6935 & $<.0001^{\star * *}$ & NA & NA & NA & NA & NA & NA & NA & NA \\
\hline CG_BOARD & NA & NA & 42.7276 & $<.0001^{* * *}$ & NA & NA & NA & NA & NA & NA \\
\hline CG_COMM & NA & NA & NA & NA & 68.4350 & $<.0001^{\star \star *}$ & NA & NA & NA & NA \\
\hline CG_SHAREH & NA & NA & NA & NA & NA & NA & 17.2490 & 0.1689 & NA & NA \\
\hline CG_DISCL ${ }_{j}$ & NA & NA & NA & NA & NA & NA & NA & NA & 58.8220 & $<.0001^{\star \star *}$ \\
\hline LAW2001 & 59.0588 & $<.0001^{* * *}$ & 63.5971 & $<.0001^{* * *}$ & 42.6378 & $<.0001^{+*+*}$ & 27.6700 & 0.2945 & 43.2420 & $<.0001^{* * *}$ \\
\hline INTERACTION & -70.8400 & $<.0001^{\star \star \star *}$ & -83.9755 & $<.0001^{* * *}$ & -85.5753 & $<.0001^{* \star \star}$ & -29.5224 & 0.4712 & -101.1000 & $<.0001^{\star \star \star}$ \\
\hline DIST_IFRS & -0.7753 & $<.0001^{* * *}$ & -0.5647 & $<0.0001^{* * *}$ & -1.0321 & $<.0001^{* * *}$ & -2.0977 & $<.0001^{* \star *}$ & -0.5724 & $<.0001^{* * *}$ \\
\hline $\mathrm{EM}_{\mathrm{j}}$ & -1.2911 & $<.0001^{* * *}$ & -0.8799 & $<0.0001^{* * *}$ & -1.2168 & $<.0001^{* * *}$ & -0.85449 & $<0.0001^{* * *}$ & -0.8889 & $<.0001^{* * *}$ \\
\hline MARKET_CAP & -0.1093 & $<.0001^{* * *}$ & -0.1695 & $<0.0001^{* * *}$ & -0.1887 & $<.0001^{* * *}$ & -0.1016 & $<.0001^{* * *}$ & -0.1298 & $<.0001^{* * *}$ \\
\hline $\operatorname{SIZE}_{\mathrm{i}}$ & 0.3560 & $<.0001^{* * *}$ & 0.3560 & $<.0001^{* * *}$ & 0.3560 & $<.0001^{* * *}$ & 0.3560 & $<.0001^{* * *}$ & 0.3560 & $<.0001^{* * *}$ \\
\hline AUDITOR $_{\mathrm{i}}$ & 0.9142 & $0.0013^{* \star *}$ & 0.9142 & $0.0013^{* \star * *}$ & 0.9142 & $0.0013^{* * t}$ & 0.9142 & $0.0013^{*+* x}$ & 0.9142 & $0.0013^{* * t}$ \\
\hline FINANCIAL_IND & -1.1957 & $0.0003^{* * *}$ & -1.1957 & $0.0003^{* * t}$ & -1.1957 & $0.0003^{* * t}$ & -1.1957 & $0.0003^{* * k}$ & -1.1957 & $0.0003^{* * t}$ \\
\hline LISTINGS $_{\mathrm{i}}$ & 0.0522 & 0.5757 & 0.0522 & 0.5757 & 0.0522 & 0.5757 & 0.0522 & 0.5757 & 0.0522 & 0.5757 \\
\hline OWNERSHIP & -0.9442 & $0.0090^{* * *}$ & -0.9442 & $0.0090^{* * * *}$ & -0.9442 & $0.0090^{* * *}$ & -0.9442 & $0.0090^{*+* x}$ & -0.9442 & $0.0090^{* * *}$ \\
\hline CAPITAL INT & -0.2000 & 0.7322 & -0.2000 & 0.7322 & -0.2000 & 0.7322 & -0.2000 & 0.7322 & -0.2000 & 0.7322 \\
\hline
\end{tabular}


Table 9: Results of the Logistic Regression with the Categories of LAW2001. ${ }^{* * *}$ significant at $1 \%$ level, ${ }^{* *}$ significant at $5 \%$ level, ${ }^{*}$ significant at $10 \%$ level

$$
\mathrm{N}=1563
$$

\begin{tabular}{|c|c|c|c|c|c|c|}
\hline Parameter & Estimate & $\mathrm{Pr}>\mathrm{ChiSq}$ & Estimate & $\mathrm{Pr}>\mathrm{ChiSq}$ & Estimate & $\mathrm{Pr}>\mathrm{ChiSq}$ \\
\hline Intercept & -89.4007 & $<.0001$ & -17.4120 & 0.0004 & -19.2213 & 0.0003 \\
\hline LAW_BOARD $_{j}$ & 168.5000 & $<.0001^{* * *}$ & NA & NA & NA & NA \\
\hline LAW_SHAREH $_{j}$ & NA & NA & 67.3056 & $<.0001^{* * *}$ & NA & NA \\
\hline LAW_DISCL & NA & NA & NA & NA & 24.7244 & $<.0001^{\star \star *}$ \\
\hline $\mathrm{CGI}_{\mathrm{j}}$ & 117.9000 & $<.0001^{* \star *}$ & 67.3537 & $<.0001^{\star \star \star}$ & 27.1154 & $<.0001^{* \star \star}$ \\
\hline INTERACTION & -153.9000 & $<.0001^{* \star \star}$ & -119.6792 & $<.0001^{* \star \star}$ & -36.6271 & $<.0001^{* \star \star}$ \\
\hline DIST_IFRS & -1.2254 & $<.0001^{* \star *}$ & -1.5794 & $<.0001^{* \star *}$ & -0.5517 & $<.0001^{* \star \star}$ \\
\hline $\mathrm{EM}_{\mathrm{j}}$ & -0.5075 & $<.0001^{* \star *}$ & -0.3498 & $<.0001^{* \star *}$ & -0.9243 & $<.0001^{* \star \star}$ \\
\hline MARKET_CAP & -0.1921 & $0.0003^{* * *}$ & -0.2351 & $<.0001^{* * *}$ & -0.1149 & $0.0005^{* * *}$ \\
\hline $\mathrm{SIZE}_{\mathrm{i}}$ & 0.3560 & $<.0001^{\star \star \star}$ & 0.3560 & $<.0001^{* \star \star}$ & 0.3560 & $<.0001^{* \star \star}$ \\
\hline AUDITOR $_{\mathrm{i}}$ & 0.9142 & $0.0013^{* \star *}$ & 0.9142 & $0.0013^{\star \star \star}$ & 0.9142 & $0.0013^{* \star \star}$ \\
\hline FINANCIAL_IND & -1.1957 & $0.0003^{* \star *}$ & -1.1957 & $0.0003^{* \star *}$ & -1.1957 & $0.0003^{\star \star \star *}$ \\
\hline LISTINGS $_{i}$ & 0.0522 & 0.5757 & 0.0522 & 0.5757 & 0.0522 & 0.5757 \\
\hline OWNERSHIP & -0.9442 & $0.0090^{\star \star \star}$ & -0.9442 & $0.0090^{\star * \star}$ & -0.9442 & $0.0090^{\star * *}$ \\
\hline CAPITAL_INT & -0.2000 & 0.7322 & -0.2000 & 0.7322 & -0.2000 & 0.7322 \\
\hline
\end{tabular}

